are trained, and even the officers led by them, to commit useless destruction, combined with eyery conceivable atrocity on man, woman, and child. It is lamentable to think of the geological and naturalhistory collections which have been destroyed in Belgium alone-a country famous for its scientific men, the work of their lives gone for ever. I trust all this will not be forgotten when the war is fought out to a proper issue, and that all Lord Walsingham suggests will come about and just punishment be thus meted out.

The German scientific man has been spoilt by success in the past; he was first in the field in many countries, particularly our own. I knew him in days gone by in India, when he fille the best appointments in the Geological Survey, the Forestry Department, etc. Many were friends of my own. In those days they were quite different men in every way from those of to-day so complete a change has come over the whole German population. It is sincerely to be hoped they will never be employed again in any capacity.

Nore Godalming, September 17.

The South Georgia Whale Fishery.

A Note on p. 470 of Nature for August I $_{5}$ contains the statement that scientific experts have, until now, not been consulted in the matter of the South Georgia whale fishery, which has been administered entirely by the Colonial Office. There is at present a considerable tendency to criticise Government Departments for failing to make use of scientific opinion, but I feel sure that you will allow me to point out that this particular criticism is not justifiable. The Colonial Office has for some years been fully alive to the fact that the regulation of subAntarctic whaling is a scientific problem, and since 1910 it has been in constant communication on the subject with the Natural History Museum. Under arrangements thus made the museum receives detailed statistics from the companies operating at South Georgia, each individual whale caught being separately recorded. Similar statistics are beginning to come in from the South Shetlands (a district almost as important as South Georgia) and from some of the African companies; while promises of returns from other whaling centres have also been received. In addition to this, the Colonial Office furnishes halfyearly and other reports on the whaling operations at the districts under its jurisdiction, and it has received many reports from the museum commenting on the facts thus recorded, and offering advice on the various questions raised.

In the course of I9I3 the Colonial Office proposed at a biologist should be sent to South Georgia to rake investigations which might contribute towards the solution of the whaling problem. In consultation with the museum, the work was offered to Major G. E. H. Barrett-Hamilton, who accepted the task, and reached South Georgia in November, I913. News of his untimely death, on January 17, 1914, while strenuously occupied with his observations on whales, was shortly afterwards received in London. The manuscript notes which he left behind show that the investigation had been placed in most competent hands, and they have formed the basis of an important report, which is at present under consideration at the Colonial Office. The appointment of Major BarrettHamilton had been made as an initial step in a much larger scheme for the investigation of the problems connected with whaling by means of a scientific station to be established for several years on the Antarctic continent. The preparations for carrying out this idea were interrupted by the war.
That the urgency of the question was recognised by Government Departments, and that the need for obtaining scientific opinion was felt, was further shown by the appointment of an Inter-Departmental Committee on Whaling and the Protection of Whales. In August, I9I3, the Colonial Office wrote to the Natural History Museum asking for information with regard to the scientific aspects of whaling for the use of this Committee, and a memorandum on the subject was submitted by the museum in due course. The Committee was engaged in hearing evidence during the first half of I9I4, but its labours were discontinued on the outbreak of war.

Early in the present year a new Committee was appointed to facilitate prompt action at the conclusion of the war in regard to the preservation of the whaling industry in the Dependencies of the Falkland Islands. This Committee, on which the Natural History Museum is represented, is actively engaged in collecting information, under the auspices of the Colonial Office.

It is sometimes assumed that expert scientific advice is capable of settling any difficult question which may arise within its own province. The solution of the problem of protecting whales is, however, no easy matter; and I doubt whether there is at present unanimity on the subject among scientific experts. The trustees of the British Museum have for some years been convinced of its importance and urgency, and they have welcomed the opportunities afforded them by the Colonial Office of expressing their views and tendering their advice, based on the study which has been given to the subject in the museum. Assistance from those competent to give it would be cordially received, and I am glad to have this opportunity of inviting scientific experts to communicate their views on the protection of whales to the Natural History Museum, and thus to assist in a matter which is not only of great zoological interest, but also one which may be described without exaggeration as of supreme national importance.

British Museum (Natural History) Cromwell Road, S.W.7.

\section{Vitality of Gorse-seed.}

Assertions regarding the length of vitality of certain seeds are frequently made, but these, when investigated, often lack proof. Hence it may be worth while to put on record a clear case of the seeds of the gorse (Ulex europaeus) retaining their germinating power for twenty-five years.

Some forty acres of gorse- and heather-covered land situated near my home in the plain of Cumberland were drained, cleaned, and ploughed out in 1893 . This area was kept in arable rotation for a number of vears; then part of it was laid down in grass in 1904, and the remainder in 1906 . It soon became evident that this new pasture would rapidly revert to a gorsecovered common unless drastic measures were taken to rid the ground of the numerous gorse seedlings, which had sprung up from the seeds brought to the surface by the last ploughing. "These were stubbed out, and in two or three years' time the ground was entirely free of gorse plants, and has continued so for the ten or more years it has been allowed to remain in permanent pasture.

Last winter this land was again brought under the plough by order of the local War Agricultural Committee, and was sown with oats. The crop has now been reaped, and gorse seedlings, 6 in. or more in height, are to be seen scattered over the stubble, being especially abundant where originally the gorse grew strongest. Evidently, then, the last ploughing has

NO. 2552 , VOL. IO 2$]$ 